\title{
Promotional Tools Employed by Medical Insurance Companies to Attract International University Students
}

\author{
Faith Rudairo Chibvura, Darry Penceliah \\ Durban University of Technology, Durban, South Africa \\ pencelid@dut.ac.za
}

\begin{abstract}
The South African Immigration Act 19 of 2004 requires that all international students have proof of medical insurance cover for the academic year of study. The medical insurance cover must be from a registered provider with the South African Council for Medical Schemes. Some medical insurance companies provide gifts to students to gain a larger market share within the educational institutions. Health insurance products are very crucial in the lives of university students and therefore the students must be familiar with medical product benefits and exclusions. It seems that many students lack relevant knowledge of health insurance products. Students seem to have a perception that medical insurance products cover all healthcare expenses. Dissatisfied customers may tarnish the image of the respective medical insurance company and result in customers seeking alternate products. The purpose of this paper is to determine the influence of promotional tools in creating awareness amongst international university students' selection of medical insurance products. The study was descriptive and quantitative in nature. Four hundred international students studying at two state universities in Durban, South Africa completed a structured questionnaire. The results indicate that the respondents are very sensitive to price and the majority of them are influenced by advertising and word of mouth. The results of the study indicated that medical insurance companies should consider the quality of service and price as being very important factors when designing a promotional mix. Awareness creation is the backbone of sales growth and market share.
\end{abstract}

Keywords: Communication, Promotional tools, Awareness and Medical Insurance.

\section{Introduction}

According to the Immigration Amendment Act 19 of 2004, all higher education institutions require proof of medical aid cover from international students before enrolment to any academic programme. Ingwe health medical facility from Momentum is the preferred by higher educational institutions. In addition, students are also free to buy any other medical product offerings for the complete calendar year. Most medical insurance companies are competing to gain market share in educational institutions. A variety of promotional tools may be used to create awareness, in the competitive medical insurance sector. Medical insurance products are very crucial to the lives of each student; therefore, the target market needs to be aware of the medical benefits and exclusions when obtaining medical insurance products. Singh (2011) stipulates that diffusion of innovation theory is very important when selecting a particular group of the target audience or a particular community. The theory of diffusion of innovation states that the concept is to be communicated and given enough time to cement in the long term. In support of this theory, social influence theory and social network theory state that the social norms of a group are considered. To sum up, the Medical Insurance companies should consider the diffusion of innovation theory so that promotional tools are implemented effectively.

An evaluation of the influence of the promotional tools employed by medical insurance companies at higher educational institutions is paramount to identify if they can create customer awareness. Research on the use of promotional tools at universities is very scanty at best, hence little is understood about the international students and their purchase behaviours, mostly with regards to the way they respond to promotional tools used by medical insurance companies (Chibvura, 2017). The questions are; is it the customer's ignorance of not searching for further information about available medical insurance products or it is the medical insurance providers' responsibility to design effective promotional tools to communicate information about what they offer? In this regard, the company may be able to maximize on retaining existing customers and gain positive publicity. Moreover, Medical Insurance Companies have experienced sales inconsistencies as the customers are not aware of the full benefits and limitations which result in over customer expectation and dissatisfaction when the actual service is delivered (Wright, Khanfar, Harrington, \& Kizer, 2010). University students seem to be lacking enough knowledge of the available medical insurance offerings. This leads to 
misinterpretation of information. Hence, dissatisfied members will tarnish the images of the respective medical insurance providers, hence customer attrition (Chibvura, 2017).

Many students have the perception that medical insurance cover all healthcare expenses. The purpose of this paper is to determine the influence of promotional tools in awareness creation amongst international university student's selection of medical insurance products. The study also explores the relationship between demographics and perception of promotional tools in creating awareness amongst international university students. Marketing to international students requires a sound understanding of demographics. This will allow for shared meaning and customised message. The following are the proposed hypotheses:

H1: There is no significant relationship between age and perception on promotional tools used in creating awareness.

H2: There is no significant relationship between gender and perception on promotional tools used in creating awareness.

H3: There is no significant relationship between race and perception on promotional tools used in creating awareness.

H4: There is no significant relationship between country of origin and perception on promotional tools used in creating awareness.

\section{Literature Review}

Various academics explain communication from the perspective of their discipline. $\mathrm{Hu}$, Lu, Khan, and Bai (2012) explain that sharing of information reminds prospects of a need that they may have or remind them of the benefits of the transactions. Communication can always explain and create awareness of a market offering to customers. Communication is the backbone of an organization as almost everything revolves around communication. Organizations give the highest significance to communication and ensure that the promotional tools frankly aim for the needs and wants of the targeted market. Brand and product awareness depend on the efficiency and effectiveness of the communication strategy of an organization and customer retention is heavily dependent on knowledge and loyalty. According to "Henry" Jin, Fawcett, and Fawcett (2013) awareness is part of the human development and as such, is necessary for a human to be aware of the situations around them. The outcome includes behaviour, inspirations, judgments and emotions. (Rajagopal, 2008) refers to customer awareness as the understandings by an individual referring to the available products marketed and sold by a firm. This avenue makes customers very much aware of their choice of the product when they are fully equipped with the product knowledge and advantages from knowing their privileges and civil liberties.

There is a need to understand the various marketing communication models that have been put forward by scholars to understand the importance of customer awareness. Thorson and Moore (2013) opine that promotional tools focus on the ways in which organizations use in notifying, convincing and reminding customers of its products and brands. Promotional tools represent the company's "voice" and their brand adds to the introduction of a channel of communication and creates long-term customer relationships. There are different promotional tools used by companies to expand and advance their communication processes and patterns. Shimp (2010) acknowledges that promotional tools stand for the compilation of all basics in a product's marketing mix, with the development of exchange by formulating mutual meaning with customers. In addition, the meaning suggests that promotional tools can either be purposeful, referring to advertising and personal selling or not purposeful as when a product attributes represent something to customers that the sales representative may not have predicted. Promotional tool communication is arguably the process of passing on information to a target market to create proposed awareness.

A promotional tool communicates different messages to consumers (Mughal, Mehmood, \& Ahmad, 2014). Hence, the lack of proper promotional tools can result in poor awareness of the product. Klink and Athaide (2014) affirm that promotional tools include advertising, personal selling, sales promotions, public relations and direct marketing elements. An organization implements a promotional mix to follow its promotional tool objectives. Armstrong, Adam, Denize, and Kotler (2014) support that the marketing purpose includes identifying consumers' needs as well as creating customer awareness, meeting and fulfilling customer needs 
and profitably. In addition to these promotional tools, a new emerging promotional tool is social media. The elasticity of the advertising tool is excellent as it implemented to formulate the message for a national segment or certain specialized market segment. Personal selling provides face-to-face interaction, which allows the sales team to get feedback and assurance of the customers' understanding.

Sales promotions involve a wide variety of tools, which includes point of purchase displays, premiums, discounts, the area of expertise advertising and demonstrations. The objective is therefore to enlarge utilization for recognized products and to motivate trial by persuading new customers to use the product. Wang, Wu, and Wang (2009) contend that direct marketing is an interactive method of marketing and which utilizes one or more advertising medium to root an assessable response and/or transaction. Mamuti (2013) rightly suggests that straight marketing seeks to target individual consumers with the purpose of providing individualized messages. According to Shimp (2010), public relations is a management function that provides visibility for an organization and thus allows it to be properly identified, positioned and understood by all its targets. Decision-making process refers to when consumers assess and evaluate many products to select the best alternative to satisfy their need (Fill, 2011). To sum up the consumer decisions making process is also very important in this study as it also influences the communication strategy and promotional tools used. There are many sources of information available to consumers such as the internet, advertising, print media and referrals. The decision to purchase originates from the evaluation of the available options. Moreover, another dimension such as product availability can also be considered.

\section{Methodology}

According to Yin (2015) research design gives a logical sequence to a researcher, which will in turn create a connection between the aim and objectives, questions of research to eventually lead to the conclusion. The data for the study was collected from international students at two public universities in South Africa using a quantitative research approach through a structured questionnaire. The questionnaire developed from the aim of the study, which was guided by the literature review.

Sample: The sample comprised full-time international university students of KwaZulu-Natal (UKZN) and Durban University of Technology (DUT). The sampling strategy for the study was largely influenced by the population representation of international students in the province of KwaZulu-Natal, South Africa. A nonprobability convenient sampling technique using a cross-sectional survey was used to select respondents. Four hundred international students studying at two state universities in Durban, South Africa completed a structured questionnaire.

Measuring Instrument: A Likert-scale structured questionnaire was used to measure the latent constructs, in this case, consumer behaviour. The questionnaire was designed in a manner that addressed the study, hence the measuring instrument managed to measure what had to be measured. These ordinal scales measure the levels of agreement/disagreement on a continuum from strongly disagree to strongly agree, thus making assumptions that behaviour can be measured. This is necessary to uncover degrees of the opinion of the respondents. A pre-test was done on a small group of university students to eliminate discrepancy and lack of clarity in some questions that affect efficiency and effectiveness. Table 1 reflects the reliability of each construct.

Data Collection Procedure: A questionnaire was distributed to a convenient sample. An enclosed letter, clearly indicating the purpose of the study, was attached to the questionnaire. A sample size of 400 international students (200 each from the two universities) was selected. A sample size of 384 should be enough to support the research results (Sekaran, 2003). Ethical considerations were adhered to in administering the questionnaire. The students' rights to anonymity, confidentiality and privacy were respected.

Reliability Statistics: The two most important aspects of precision are reliability and validity. Reliability computed by taking several measurements on the same subjects. A reliability coefficient of 0.70 or higher is considered as "acceptable". 
Table 1: Cronbach's Alpha

\begin{tabular}{lll}
\hline & Number of Items & Cronbach's Alpha \\
\hline Effectiveness of promotional tools & 9 & 0.817 \\
Perception on promotional tools in creating awareness & 7 & 0.737 \\
Information source & 8 & 0.804 \\
\hline
\end{tabular}

The reliability scores for all sections exceed the recommended Cronbach's alpha value. This indicates a degree of acceptable, consistent scoring for these sections of the research.

Factor Analysis: Factor analysis is used to find latent variables or factors among observed (Tustin \& Martins). Table 2 reflects the summarized results of KMO and Bartlett's Test. The requirement is that KaiserMeyer-Olkin Measure of Sampling Adequacy should be greater than 0.50 and Bartlett's Test of Sphericity less than 0.05 . In all instances, the conditions are satisfied which allows for the factor analysis procedure.

Table 2: KMO and Bartlett's Test

\begin{tabular}{lcccc}
\hline Description & $\begin{array}{c}\text { Kaiser-Meyer-0lkin } \\
\text { Measure of } \\
\text { sampling } \\
\text { Adequacy }\end{array}$ & $\begin{array}{c}\text { Bartlett's Test of } \\
\text { Sphericity } \\
\text { Approx. } \\
\text { Chi-square }\end{array}$ \\
& & DF & Sig \\
\hline Decision Making Process & 0.826 & 640.438 & 21 & 0.000 \\
Effectiveness of promotional tools & 0.807 & 1053.212 & 36 & 0.000 \\
Perception of promotional tools used in creating awareness & 0.746 & 554.674 & 21 & 0.000 \\
\hline
\end{tabular}

All of the conditions are satisfied for factor analysis. This means that the variables that constituted the research instrument were perfect measures of the component. Overall, it can be concluded that the sections on the research instrument measured exactly what they were intended to measure.

\section{Results and Discussion}

There were 400 responses from the target university students. The biographical dimensions in this study include gender, age, country of origin and religion. Biographical data provides an understanding of the respondents' groups. The analysis of respondent's characteristic reflected in Table 3.

Table 3: Demographic Statistics of Respondents

\begin{tabular}{|c|c|c|c|c|c|c|c|}
\hline Age & $\%$ & Religion & $\%$ & Origin & $\%$ & Gender & $\%$ \\
\hline $18-21$ & 27.5 & Christianity & 76,3 & Botswana & 8.5 & Male & 62 \\
\hline $22-25$ & 42.5 & Islamic & 13.5 & Zimbabwe & 34.3 & Female & 37 \\
\hline $26-36$ & 22.5 & Traditional & 5.5 & Congo & 7 & & \\
\hline \multirow[t]{13}{*}{$31+$} & 7.5 & Hinduism & 4.8 & Nigeria & 11 & & \\
\hline & & & & Uganda & 11.3 & & \\
\hline & & & & Germany & 10.8 & & \\
\hline & & & & Swaziland & 5.8 & & \\
\hline & & & & Namibia & 5 & & \\
\hline & & & & Zambia & 3.8 & & \\
\hline & & & & India & 0.8 & & \\
\hline & & & & Sweden & 0.8 & & \\
\hline & & & & Burundi & 0.3 & & \\
\hline & & & & Lesotho & 0.3 & & \\
\hline & & & & Angola & 0.3 & & \\
\hline & & & & Sierra Leone & 0.3 & & \\
\hline & & & & Mali & 0.3 & & \\
\hline
\end{tabular}


Most of the respondents fall within the 22-25 age range. In addition, the male students participated more in the research project as compared to females. Three-quarters of the population belongs to the Christianity religion. Most of the international students come from neighbouring African countries such as Zimbabwe and Nigeria. The age group of $30+$ has shown no significant contribution to the study as compared to other age groups. According to Guo, Hu, and Wan (2008), the university population, which is in the age of 31+, is very small as there are very few students doing their masters and doctorate degrees as compared to undergraduate students. The following patterns are observed. Some statements show (significantly) higher levels of importance whilst other levels of agreement are lower (but still greater than levels of importance). There are no statements indicating higher levels of little importance. The respondents regard the quality of service as the most important factor they consider when selecting medical insurance. This means the majority of the students consider the quality of service when it comes to medical insurance. Availability of adequate information was rated as the second important factor to consider when selecting medical insurance.

Table 4: Effectiveness of Promotional Tools

\begin{tabular}{|c|c|c|c|c|c|c|c|}
\hline & & $\begin{array}{l}\text { Of } \\
\text { impor }\end{array}$ & $\begin{array}{l}\text { little } \\
\text { nce }\end{array}$ & Neutra & & Impor & \\
\hline & & Count & $\begin{array}{l}\text { Row N } \\
\%\end{array}$ & Count & $\begin{array}{l}\text { Row N } \\
\%\end{array}$ & Count & $\begin{array}{l}\text { Row N } \\
\%\end{array}$ \\
\hline The use of university broadcast email & $\mathrm{C} 13$ & 38 & $9.5 \%$ & 89 & $22.3 \%$ & 273 & $68.3 \%$ \\
\hline Advertising on University websites & C14 & 30 & $7.5 \%$ & 59 & $14.8 \%$ & 311 & $77.8 \%$ \\
\hline $\begin{array}{l}\text { Exhibitions by medical insurance companies } \\
\text { during university opening days }\end{array}$ & C15 & 28 & $7.0 \%$ & 38 & $9.5 \%$ & 334 & $83.5 \%$ \\
\hline $\begin{array}{l}\text { Internet (social media , for instance } \\
\text { Facebook and YouTube) }\end{array}$ & C16 & 38 & $9.5 \%$ & 59 & $14.8 \%$ & 303 & $75.8 \%$ \\
\hline Newspaper and magazines adverts & C17 & 44 & $11.0 \%$ & 61 & $15.3 \%$ & 295 & $73.8 \%$ \\
\hline Advertising on University radio slots & C18 & 47 & $11.8 \%$ & 71 & $17.8 \%$ & 281 & $70.4 \%$ \\
\hline Events sponsorship & C19 & 37 & $9.3 \%$ & 79 & $19.8 \%$ & 284 & $71.0 \%$ \\
\hline $\begin{array}{l}\text { Sales promotions (gifts with company name } \\
\text { printed on it) }\end{array}$ & $\mathrm{C} 20$ & 43 & $10.8 \%$ & 51 & $12.8 \%$ & 306 & $76.5 \%$ \\
\hline Personal selling around university campuses & $\mathrm{C} 21$ & 30 & $7.5 \%$ & 64 & $16.0 \%$ & 306 & $76.5 \%$ \\
\hline
\end{tabular}

83.5\% of the respondents consider the exhibitions by medical insurance companies during university open days to be the most important promotion tool. Moreover, according to Coetzee and Liebenberg (2004) open days' exhibitions are the most used sources of information at universities. Respondents also consider almost all promotional tools equally important. In addition, the findings of this study are supported with the results, (Jones, 2002) where respondents perceived open days' exhibitions as a vital source of information and effective promotional tool. The average level of high importance is $74.83 \%$, which reflects that all the promotional tools are also regarded as highly important as well. Thorson and Moore (2013) confirm that a promotional mix is needed to notify, convince and remind customers of the market offerings. $75.8 \%$ of the respondents concurred that internet (social media) contributes to a greater extent a promotional tool for medical insurance.

Overall, it can be deduced that the respondents are very active on the social networks, which makes them receive, access and decode the information easily. Moreover, at Durban University of Technology and the University of KwaZulu-Natal every international student is a member of the international student Facebook page, which makes it very easy to disseminate information to everyone involved. Recommended medical insurance companies have made use of the international students' Facebook page platform to advertise. 
Social networks connect students from different faculties together (Hu et al., 2012). According to ("Henry" Jin et al., 2013) internet (social media) is a considerable marketing advance to which many tertiary institutions use as a promotional tool. Loda (2014) who states that the digital revolution has already changed almost everything about how business is conducted in the medical insurance industry and it has greatly benefited from the new emerging opportunities offered by the Internet.

Laranjo et al. (2014), state that the Internet especially through the social media platform has changed how marketers and consumers communicate. Al Kailani and Kumar (2011) rightly suggest that one of the main advantages of the Internet is that it enables marketing practitioners to reach a worldwide customer segment, so that prospective customers and actual customers can search, select, and purchase products from suppliers around the world. Sales promotions and personal selling are regarded as equally important as promotional tools for medical insurance with a percentage of 76.5\%. Most of the respondents also rate these promotional tools as highly important as well. Fandos Roig, García, and Moliner Tena (2009) argue that, when it comes to services, customers believe so much in personal selling as compared to other promotional tools which do not provide personal contact with the customer which ensure understanding of the provided information. The results also indicate that the respondents believe that university website, broadcast email and radio slots are also important promotional tools for medical insurance with the respondents' percentages of 77.8, 68.3 and 70.4 respectively

Table 5: Perception of Promotion Tools Used in Creating Awareness

\begin{tabular}{|c|c|c|c|c|c|c|c|}
\hline & & \multicolumn{2}{|c|}{ Disagree } & \multicolumn{2}{|c|}{ Neutral } & \multicolumn{2}{|l|}{ Agree } \\
\hline & & Count & $\begin{array}{l}\text { Row } \\
\mathrm{N} \%\end{array}$ & Count & $\begin{array}{l}\text { Row } \\
\mathrm{N} \%\end{array}$ & Count & $\begin{array}{l}\text { Row } \\
\mathrm{N} \%\end{array}$ \\
\hline $\begin{array}{l}\text { TV adverts reinforces brand awareness for } \\
\text { medical insurance companies }\end{array}$ & $\begin{array}{l}\mathrm{D} 2 \\
2\end{array}$ & 23 & $5.8 \%$ & 50 & $\begin{array}{l}12.5 \\
\%\end{array}$ & 327 & $\begin{array}{l}81.8 \\
\%\end{array}$ \\
\hline $\begin{array}{l}\text { Giving branded gifts creates awareness for } \\
\text { medical insurance companies }\end{array}$ & $\begin{array}{l}\mathrm{D} 2 \\
3\end{array}$ & 40 & $\begin{array}{l}10.0 \\
\%\end{array}$ & 59 & $\begin{array}{l}14.8 \\
\%\end{array}$ & 301 & $\begin{array}{l}75.3 \\
\%\end{array}$ \\
\hline $\begin{array}{l}\text { Sponsorships towards international students' } \\
\text { events creates awareness }\end{array}$ & $\begin{array}{l}\mathrm{D} 2 \\
4\end{array}$ & 40 & $\begin{array}{l}10.0 \\
\%\end{array}$ & 53 & $\begin{array}{l}13.3 \\
\%\end{array}$ & 307 & $\begin{array}{l}76.8 \\
\%\end{array}$ \\
\hline $\begin{array}{l}\text { Personal selling through direct contact with the } \\
\text { students provides information on the available } \\
\text { medical insurance companies. }\end{array}$ & $\begin{array}{l}\mathrm{D} 2 \\
5\end{array}$ & 25 & $6.3 \%$ & 42 & $\begin{array}{l}10.5 \\
\%\end{array}$ & 333 & $\begin{array}{l}83.3 \\
\%\end{array}$ \\
\hline $\begin{array}{l}\text { Internet Adverts keep on reminding students } \\
\text { about available medical insurance companies. }\end{array}$ & $\begin{array}{l}\text { D2 } \\
6\end{array}$ & 32 & $8.0 \%$ & 48 & $\begin{array}{l}12.0 \\
\%\end{array}$ & 320 & $\begin{array}{l}80.0 \\
\%\end{array}$ \\
\hline $\begin{array}{l}\text { Facebook and all other social networks } \\
\text { contribute to a greater extent in creating } \\
\text { awareness for students }\end{array}$ & $\begin{array}{l}\mathrm{D} 2 \\
7\end{array}$ & 28 & $7.0 \%$ & 50 & $\begin{array}{l}12.5 \\
\%\end{array}$ & 322 & $\begin{array}{l}80.5 \\
\%\end{array}$ \\
\hline $\begin{array}{l}\text { Word of mouth creates awareness to a greater } \\
\text { extent to students. }\end{array}$ & $\begin{array}{l}\mathrm{D} 2 \\
8\end{array}$ & 25 & $6.3 \%$ & 43 & $\begin{array}{l}10.8 \\
\%\end{array}$ & 332 & $\begin{array}{l}83.0 \\
\%\end{array}$ \\
\hline
\end{tabular}

Medical insurance companies usually sponsor international students' sports day every year through the International office of the University. The significance of assessing the effectiveness of each promotional tool used by medical insurance was to analyse if the promotional tools are creating awareness and the results reflect that exhibitions during university open days are the most effective. The highest percentage of $83.3 \%$ of the respondents have the perception that personal selling through direct contact with the students provides information on the available medical insurance companies. Fill (2011) supports that personal selling provides face-to-face interaction with customers, which allows the sales team to get feedback and assurance of the customers' understanding. This is followed by the perception that word of mouth creates awareness to a greater extent to students. From the previous research by Jones (2002) word of mouth was ranked as the most effective promotional tool for the students. In the medical insurance industry, word of mouth is very important as students make decisions through referrals from parents or family. According to Shrivastava, 
Londhe, Sonawane, and Suri (2016) many students believe that word of mouth is effective in creating awareness as students share their knowledge about medical insurance.

TV adverts reinforce brand awareness with $81.8 \%$. From the above results, it is worth mentioning that the majority of the students agreed that TV advertising, advertising through social networks and personal selling creates awareness and provides information on the available medical insurance. Soba and Aydin (2013) state that advertising can make $70 \%$ of the target market aware of the new product, achieving $50 \%$ understanding of a proposition, with $40 \%$ convinced and $20 \%$ will purchase in the first period. Overall, it can be concluded that the majority of international students are active in the sport, which makes it successful for the medical insurance companies to sponsor sports events giving away branded gifts. It can also be concluded that most students had access to the internet at the institutions as they have agreed that internet adverts revive brand awareness Gifts offered when joining are also considered important when selecting medical insurance. Petruzzellis and Romanazzi (2010) believe factors considered depend on the type of product offered, functional value, emotional value, social value, price and quality.

Table 6: Information Source

\begin{tabular}{|c|c|c|c|c|c|c|c|}
\hline & & \multicolumn{2}{|c|}{ Disagree } & \multicolumn{2}{|c|}{ Neutral } & \multicolumn{2}{|l|}{ Agree } \\
\hline & & Count & $\begin{array}{l}\text { Row N } \\
\%\end{array}$ & Count & $\begin{array}{l}\text { Row N } \\
\%\end{array}$ & Count & $\begin{array}{l}\text { Row N } \\
\%\end{array}$ \\
\hline Word of mouth from other students & E29 & 32 & $8.0 \%$ & 56 & $14.0 \%$ & 312 & $78.0 \%$ \\
\hline $\begin{array}{l}\text { Sales presentation by a } a \\
\text { company representative around campus }\end{array}$ & E30 & 35 & $8.8 \%$ & 53 & $13.3 \%$ & 312 & $78.0 \%$ \\
\hline Internet browsing & E31 & 45 & $11.3 \%$ & 74 & $18.5 \%$ & 281 & $70.3 \%$ \\
\hline University pamphlets & E32 & 42 & $10.5 \%$ & 87 & $21.8 \%$ & 271 & $67.8 \%$ \\
\hline University websites & E33 & 56 & $14.0 \%$ & 68 & $17.0 \%$ & 276 & $69.0 \%$ \\
\hline TV adverts & E34 & 58 & $14.5 \%$ & 69 & $17.3 \%$ & 273 & $68.3 \%$ \\
\hline Radio Advert & E35 & 77 & $19.3 \%$ & 79 & $19.8 \%$ & 244 & $61.0 \%$ \\
\hline Received branded gifts & E36 & 61 & $15.3 \%$ & 62 & $15.5 \%$ & 277 & $69.3 \%$ \\
\hline
\end{tabular}

The majority of the respondents got information from word of mouth and sales presentations, followed by internet browsing and all the other sources of information with the average level of agreement of $70.19 \%$. Word of mouth is ranked as the first used source of information that influenced the student's decision making on medical insurance because students rely on advice from parents, family members and friends. According to the study by (Konyana, 2013) word of mouth was rated the third while in the study done by Jones (2002) word of mouth was ranked as the most effective source of information by the respondents. In addition, Klink and Athaide (2014) state that when it comes to medical insurance and any other services reference group influence through word of mouth is very crucial. Furthermore, personal selling has the highest percentage of agreement. This indicates that the majority of the respondents have received information through personal selling. Kotler and Keller (2012) support that personal selling is the most effective tool at particular steps of the customer buying process particularly in creating up buyer's awareness, tastes, conviction and activities. A similar study by Fandos Roig et al. (2009) highlight that through personal selling, the consumer usually feels a bigger need to pay more attention, listen and act in response.

Hypothesis Testing: The traditional approach to reporting a result requires a statement of statistical significance. A p-value is generated from a test statistic. A significant result is indicated with "p < 0.05". A second Chi-square test was performed to determine whether there was a statistically significant relationship between the variables (rows vs. columns). The null hypothesis states that there is no association between the two. The alternate hypothesis indicates that there is an association. The tables below summarize the results 
of the chi-square tests. The results of this study indicated that medical insurance companies should consider the quality of service and price as being very important factors when designing a promotional mix.

\begin{tabular}{lll} 
Table 7: Relationship between Age and Perception on Promotional Tools Used in Creating Awareness \\
\hline Item & $\mathbf{X}^{2}$ & $\mathbf{P}$ \\
\hline TV adverts reinforce brand awareness for medical insurance companies. & 29.056 & 0.040 \\
Giving branded gifts creates awareness for medical insurance companies. & 10.387 & 0.582 \\
Sponsorship towards international students' events creates awareness. & 17.124 & 0.145 \\
Personal selling through direct contact with the students provides information on the & 15.982 & 0.192 \\
available medical insurance companies. & & \\
Internet adverts keep on reminding students about available medical insurance & 18.607 & 0.098 \\
companies. & & \\
Facebook and all other social networks contribute largely to creating awareness to & 16.888 & 0.154 \\
students. & 14.284 & 0.283 \\
\hline
\end{tabular}

As indicated in Table 7, it emerged that there was no significant relationship between age groups and most of the seven items that measure respondent perception on promotional tools used in creating awareness ( $p$ is greater than 0.05). However, the results also show that there is a relationship between age and one item saying that TV adverts reinforce brand awareness for medical insurance companies ( $\mathrm{p}$ is less than 0.05). Therefore, the hypothesis that there is no significant relationship between age and perception on promotional tools used to create awareness is highly accepted.

Table 8: Relationship between Gender and Perception on Promotional Tools Used in Creating Awareness

\begin{tabular}{lll}
\hline Item & $\mathbf{X}^{2}$ & $\mathbf{P}$ \\
\hline TV adverts reinforce brand awareness for medical insurance companies. & 2.752 & 0.600 \\
Giving branded gifts creates awareness for medical insurance companies. & 12.697 & 0.013 \\
Sponsorship towards international students' events creates awareness. & 7,217 & 0.125 \\
Personal selling through direct contact with the students provides information on the & 5.120 & 0.275 \\
available medical insurance companies. & & \\
Internet adverts keep on reminding students about available medical insurance companies. & 2.025 & 0.731 \\
Facebook and all other social networks contribute largely to creating awareness to & 1.457 & 0.834 \\
students. & & \\
Word of mouth creates awareness to a greater extent to students & & \\
\hline
\end{tabular}

As reflected in Table 8, there is no significant relationship between gender and perception on promotional tools used in creating awareness for the medical product as the $\mathrm{p}$ values of six out of seven items are greater than 0.05 except only one item with a p-value of 0.013 . Therefore, there is only a significant relationship between gender and giving branded gifts as a way of creating awareness for medical insurance companies. The hypothesis that there is no significant relationship between gender and perception on promotional tools used in creating awareness is accepted.

Table 9: Relationship between Race and Perception on Promotional Tools Used in Creating Awareness

\begin{tabular}{lll}
\hline Item & $\mathbf{X}^{\mathbf{2}}$ & $\mathbf{P}$ \\
\hline TV adverts reinforce brand awareness for medical insurance companies. & 11.887 & 0.455 \\
Giving branded gifts creates awareness for medical insurance companies. & 19.237 & 0.083 \\
Sponsorship towards international students' events creates awareness. & 24.778 & 0.016 \\
Personal selling through direct contact with the students provides information on the & 12.170 & 0.432 \\
available medical insurance companies. & & \\
Internet adverts keep on reminding students about available medical insurance companies. & 13.026 & 0.367 \\
Facebook and all other social networks contribute largely to creating awareness to & 12.277 & 0.424 \\
students. & & \\
Word of mouth creates awareness to a greater extent to students & 24.457 & 0.018 \\
\hline
\end{tabular}


From the above results in Table 9, it indicates that there is no significant relationship between race and perception on promotional tools used in creating awareness for the medical product as the $\mathrm{p}$ values of five items out of seven items are greater than 0.05 except only two items with a p-value of 0.016 and 0.018 . The hypothesis that there is no significant relationship between race and perception on promotional tools used in creating awareness is therefore accepted.

Table 10: Relationship between Country of Original and Perception on Promotional Tools used in Creating Awareness

\begin{tabular}{lll}
\hline Item & $\mathbf{X}^{2}$ & $\mathbf{P}$ \\
\hline TV adverts reinforce brand awareness for medical insurance companies. & 91.594 & 0.005 \\
Giving branded gifts creates awareness for medical insurance companies. & 75.421 & 0.087 \\
Sponsorship towards international students' events creates awareness. & 63.923 & 0.340 \\
$\begin{array}{l}\text { Personal selling through direct contact with the students provides information on the } \\
\text { available medical insurance companies. }\end{array}$ & 33.914 & 0.997 \\
$\begin{array}{l}\text { Internet adverts keep on reminding students about available medical insurance companies. } \\
\text { Facebook and all other social networks contribute largely to creating awareness to }\end{array}$ & 31.217 & 0.999 \\
students. & 43.542 & 0.946 \\
Word of mouth creates awareness to a greater extent to students & 64.664 & 0.317 \\
\hline
\end{tabular}

As reflected in Table 10, there is no significant relationship between country of origin and perception on promotional tools used in creating awareness for the medical product as the $\mathrm{p}$ values of six items out of seven items are greater than 0.05 except only one item with a p-value of 0.005 . Therefore, there is only a significant relationship between country of origin and the item, which says that TV adverts reinforce brand awareness for medical insurance companies. The hypothesis that there is no significant relationship between country of origin and perception on promotional tools used in creating awareness is accepted. The inferential statistics are reflected in Table 1 and Table 2.

\section{Conclusion}

Students consider price, how popular the medical insurance company is, company's reputation, incentives offered when joining, benefits and limitations of insurance packages, quality of service and availability of adequate information prior to making their selection. All these factors influence the decision-making process of the students and they carry different weights of importance towards the final decision, despite that some are being ignored. The findings indicate that the source of information is very important in assessing awareness creation. The majority of the students agree that word of mouth creates awareness largely, yet some of the students are not satisfied. All promotional tools are considered very effective despite the infrequent use of some of them such as, printed media, university radio slots, and university broadcast email. Most of the respondents perceive that word of mouth and personal selling creates awareness.

Promotional tools, which involve two-way communication, regarded as the most effective. Two-way communication was possible when feedback was obtained from the customers and when there was personal interaction between the marketer and the customers. Students reacted differently towards various promotional tools; therefore, an effective promotional mix was required. Positive information on products should be available and accessible on all credible sources of information. Understanding the nature of the target market and the nature of the product was regarded as vital when designing a promotional tool. Awareness creation is the backbone of sales growth and market share. An understanding and correct implementation of the customer-oriented promotional mix was regarded as paramount for medical insurance. This shows that medical insurance companies should make use of promotional tools effectively to create awareness and provide adequate information.

\section{References}

Al Kailani, M. \& Kumar, R. (2011). Investigating uncertainty avoidance and perceived risk for impacting Internet buying: A study in three national cultures. International Journal of Business and Management, 6(5), 76. 
Armstrong, G., Adam, S., Denize, S. \& Kotler, P. (2014). Principles of marketing: Pearson Australia.

Chibvura, F. R. (2017). Promotional tools used by medical insurance companies: an international student perspective. M.Man.Sc. (Marketing), Durban University of Technology.

Coetzee, M. \& Liebenberg, E. (2004). The influence of corporate reputation on the choice of the University of Pretoria as a preferred HEI: a survey of high-school learners in the Pretoria region. Unpublished honours dissertation, University of Pretoria, Pretoria.

Fandos Roig, J. C., García, J. S. \& Moliner Tena, M. Á. (2009). Perceived value and customer loyalty in financial services. The Service Industries Journal, 29(6), 775-789.

Fill, C. (2011). Essentials of marketing communications: Financial Times Prentice Hall Englewood Cliffs, NJ.

Guo, Y. G., Hu, J. S. \& Wan, L. J. (2008). Nanostructured materials for electrochemical energy conversion and storage devices. Advanced Materials, 20(15), 2878-2887.

"Henry" Jin, Y., Fawcett, A. M. \& Fawcett, S. E. (2013). Awareness is not enough: Commitment and performance implications of supply chain integration. International Journal of Physical Distribution \& Logistics Management, 43(3), 205-230.

Hu, Y., Lu, F., Khan, I. \& Bai, G. (2012). A cloud computing solution for sharing healthcare information. Paper presented at The 7th International Conference for Internet Technology and Secured Transactions (ICITST).

Jones, M. (2002). The effectiveness of marketing communication strategies employed by universities and technikons in the Cape Peninsula with specific reference to career exhibitions and open days in attracting first-year students. Peninsula Technikon,

Klink, R. R. \& Athaide, G. A. (2014). Examining the brand name-mark relationship in emerging markets. Journal of Product \& Brand Management, 23(4/5), 262-267.

Konyana, S. V. M. (2013). Promotional tools at selected universities in the Tshwane Metropolitan Region. M.Tech (Marketing), Durban University of Technology.

Kotler, P. \& Keller, K. (2012). Marketing management, Praha: Grada Publishing.

Laranjo, L., Arguel, A., Neves, A. L., Gallagher, A. M., Kaplan, R., Mortimer, N. \& Lau, A. Y. (2014). The influence of social networking sites on health behavior change: a systematic review and meta-analysis. Journal of the American Medical Informatics Association, 22(1), 243-256.

Loda, M. D. (2014). Suggesting a More Effective Way to Use the Promotional Mix in Services. Services Marketing Quarterly, 35(4), 304-320.

Mamuti, A. (2013). The use of celebrity endorsement as a marketing communication strategy by Turkish Airlines. Journal of African business, 12, 79-89.

Mughal, A., Mehmood, A. \& Ahmad, B. (2014). The Impact of Promotional Tools on Consumer Buying Behavior: A Study from Pakistan. Journal of Public Administration and Governance, 4(3), 402-414.

Petruzzellis, L. \& Romanazzi, S. (2010). Educational value: how students choose university: Evidence from an Italian university. International journal of educational management, 24(2), 139-158.

Rajagopal, D. (2008). Point of sales promotions and buying stimulation in retail stores. Psychology and Marketing, 68(2), 871-894.

Sekaran, U. (2003). Research methods for business . Hoboken: John Wiley \& Sons.

Shimp, T. (2010). Advertising, Promotion \& other aspects of Integrated Marketing Communications. $8^{\text {th }}$ ed. South Western: Cengage Learning.

Shrivastava, V. K., Londhe, N. D., Sonawane, R. S. \& Suri, J. S. (2016). Computer-aided diagnosis of psoriasis skin images with HOS, texture and color features: a first comparative study of its kind. Computer methods and programs in biomedicine, 126, 98-109.

Singh, S. (2011). Influencing behavioural change by customer engagement amongst youth. Adolescent Health, Medicine and Therapeutics, 2(1), 123-132.

Soba, M. \& Aydin, M. (2013). Product placement efficiency in marketing communication strategy. International Journal of Business and Management, 8(12), 111.

Thorson, E. \& Moore, J. (2013). Integrated communication: Synergy of persuasive voices: Psychology Press.

Tustin, D. L. \& Martins, A. J. H. \& Van Wyk, H. J. (2005). Marketing Research in Practice. Pretoria: Unisa Press.

Wang, Y. S., Wu, M. C. \& Wang, H. Y. (2009). Investigating the determinants and age and gender differences in the acceptance of mobile learning. British journal of educational technology, 40(1), 92-118.

Wright, E., Khanfar, N. M., Harrington, C. \& Kizer, L. E. (2010). The lasting effects of social media trends on advertising. Journal of Business \& Economics Research, 8(11), 73-80.

Yin, R. (2015). Case study research: design and methods. London: SAGE Publications. 